\title{
Die tweede erediens
}

\author{
M J du P Beukes \\ Universiteit van Pretoria
}

\begin{abstract}
Evening Service
\end{abstract}

For many years the evening service of the Afrikaans speaking churches has been unsuccessful as far as attendances are concerned. Many endeavours to improve this have failed. This study is an attempt to argue that the Bible and history do not insist on an evening meeting of the church on Sunday, especially not as a second service. In the light of biblical and historical facts the problem of the evening service could be resolved if, in every parish, there were a service on Sunday as well as other types of gatherings, including an educational meeting, which could be held at different times, according to local demands.

\section{RELEVANSIE VAN DIE TEMA}

Die Algemene Kerkvergadering van die Nederduitsch Hervormde Kerk van Afrika het in 1983 (Notule Algemene Kerkvergadering 1983:3) besluit:

Die vergadering gee opdrag aan die Algemene Kommissie om ondersoek te laat instel na die moontlikheid en die wenslikheid om die tweede erediens op Sondae 'n ander vorm te gee. Die resultate word in oorleg met die Algemene Kommissie deurgegee na gemeentes.

Die Algemene Kommissie van die Nederduitsch Hervormde Kerk van Afrika het hierdie opdrag na die Kerk se Raad vir Prediking en Erediens verwys. Na verslag deur die Raad vir Prediking en Erediens het die Algemene Kerkvergadering besluit om die aanbevelings van die $\mathbf{R a a d}$ in beginsel te aanvaar maar dat verdere besinning nodig is voordat dit geïmplimenteer kan word (Notule Agenda Algemene Kerkvergadering 1989a:38, 70). 
Met die oog op verdere besinning is die volgende aanvaar:

- Die Sondag moet optimaal tot verheerliking van God en tot opbou van die gemeente benut word.

* Om dit te bereik, moet minstens een erediens per Sondag gehou word. Kerkrade beplan die gemeenteprogram sodanig dat die predikant voldoende tyd kry vir voorbereiding vir die totale erediens, wat prediking en liturgie insluit.

* In elke gemeente kan op Sondag, naas die moontlikheid van 'n tweede erediens, ook meerdere byeenkomste van die gemeente gehou word. Hierdie byeenkomste se tyd, plek en vorm word deur die kerkraad bepaal.

Die tweede byeenkoms van die gemeente kan die volgende wees:

- 'n gewone erediens met of sonder sakramentbediening;

- 'n liturgiese diens;

- 'n Bybelstudiegeleentheid;

- 'n gesamentlike erediens van die Hervormde gemeentes in een dorp of ring;

- 'n byeenkoms met die klem op sang en musiek.

- Ringskommissies hou noulettend opsig oor elke gemeente se Sondagviering. Slegs in oorleg met die ringskommissie kan 'n gemeente minder as twee byeenkomste op 'n Sondag hou.

- Toerustingskursusse oor gewone en besondere eredienste vir ampsdraers en lidmate moet beplan word. Hierdie kursusse word vir predikante by die SVTT aangebied en word as verpligtend vir hulle gestel. Op gemeentelike vlak word die kursusse aangebied deur die predikante en ander kundige persone (Notule Algemene Kerkvergadering 1989a:38).

Hierdie artikel is geskryf met die oog op 'n sinvolle gesprek op die 1992 Algemene Kerkvergadering van die Nederduitsch Hervormde Kerk.

Die swak bywoning van die tweede erediens op die Sondag in die Nederduitsch Hervormde Kerk is 'n verdere rede tot voortgaande besinning. In 1975 het slegs ses persent van die plattelandse gemeentes gereeld twee eredienste op 'n Sondag gehou. Die bywoning van hierdie gemeentes ten opsigte van die tweede erediens het gewissel tussen sewe en vyftien persent (Van der Westhuizen 1975:131). As in aanmerking geneem word dat 'n verdere elf persent van die plattelandse gemeentes op daardie stadium periodiek twee dienste gehou het en die res van die plattelandse gemeentes $(83 \%)$ geen tweede erediens gehou het nie, was die totale bywoning op daardie stadium baie laag. In dieselfde jaar het slegs ses persent van die lidmate in stede en dorpe die tweede erediens bygewoon en slegs vier persent gedurende langnaweke en vakansies (Van Wyk 1975:144). In 1979 het die kerk na aanleiding van 
die ondersoeke van Van der Westhuizen en Van Wyk besluit dat twee eredienste op 'n Sondag in al die gemeentes van die Nederduitsch Hervormde Kerk van Afrika gehou moet word. Die verwagting was 'n aansienlike verbetering in die bywoning. Volgens J A Beukes se ondersoek in 1988 bet hierdie verbetering nie plaasgevind nie. In 1988 het 79,62 persent van die plattelandse gemeentelede en 58,23 persent van die stadsgemeentelede nog steeds geen tweede erediens bygewoon nie. Gemiddeld 67,31 persent van al hierdie kerk se lidmate het geen tweede erediens bygewoon nie. Slegs 5,07 van die kerk se lidmate het in 1988 gereeld die tweede erediens bygewoon (Beukes 1989:19).

Indien ontstellende feite soos hierdie ter tafel kom, kan die kerk nie net daarvan kennis neem nie, maar vra dit diepgaande besinning veral vanuit die geledere van die Praktiese Teologie.

Die probleem rondom die tweede erediens loop breër as die Nederduitsch Hervormde Kerk van Afrika. Hier te lande was dit veral A C Barnard en L C Dressel wat besondere aandag aan die bywoning, die prinsipiële gronde, die probleme en moontlike oplossings vir die tweede erediens na vore gebring het (Barnard 1987; Dressel 1987).

Net soos in die geval van die Nederduitsch Hervormde Kerk van Afrika is die bywoning van die tweede erediens in die Nederduitse Gereformeerde kerk ook baie swak. Volgens Barnard was die gemiddelde bywoning van die tweede erediens in 1985 in hierdie kerk slegs 9.5 persent (Barnard 1987:1).

Die probleem ten opsigte van die bywoning van die tweede erediens het reeds op die Sinode van Dordtrecht 1618-1619 voorgekom. Hierdie Sinode moes al maatreëls tref om die swak bywoning van die tweede diens te bekamp (Van Zyl 1987:1).

Die probleme rondom die tweede erediens het 'n aantal jare vantevore ook in Nederland baie sterk na vore gekom. Barnard verwys na J T Bakker en Brillinburg Wurth wat hulle intensief met hierdie probleem besig gehou het. Wurth verwys na die afname in bywoning van die tweede erediens en Bakker oordeel dat die aanderediens nie meer lank sal voortbestaan nie. By ons geld dit ook dat we druk bezig zijn deze tweede dienst te verspelen. Het hoeft nog maar een paar jaar zo door te gaan en het probleem lost zich vanzelf op eenvoudig omdat er dan helemal niet meer is' (Barnard 1987:1).

In die Nederduitsch Hervormde Kerk van Afrika was daar nie altyd eenstemmigheid ten opsigte van die handhawing van die tweede erediens op Sondag nie. Wyle prof E A Mulder sou die siening gehad het dat indien ' $n$ lidmaat een diens bywoon, daar geen gewone noodsaak is om die tweede ook by te woon nie. Wyle ds Barger sou van mening gewees het dat 'n predikant nie gereeld twee goeie preke per Sondag kan lewer nie. In hierdie opsig vra 'n mens jouself af in hoe verre twee swak 
preke per Sondag minder goed is vir kerkgang as een preek waarin die allerbeste Woordbediening die wagwoord is (Van der Westhuizen 1976:86)?

Ds H J van Staden het in 1976 hierby aangesluit in 'n uitspraak op die Algemene Kerkvergadering: 'Dit is nie meer billik om van lidmate te verwag om twee keer op 'n Sondag eredienste by te woon nie. As daar net een diens gehou word, sal dit deur meer mense bygewoon word as in die geval van twee dienste' (Van Staden, in Van Zyl 1987:3).

\section{DOELSTELING VAN ARTTKEL}

Met hierdie artikel wil ek probeer aantoon dat die tweede erediens op Sondag nie prinsipieel noodsaaklik is nie, die tweede byeenkoms van die gemeente nie noodwendig in die aand moet plaasvind nie en dat die tweede byeenkoms van die gemeente op 'n Sondag 'n ander vorm as die eerste kan aanneem. Hierdie studie wil nie poog om die gelowige se geloofsuitlewing in die gemeente op die Sondag te verminder nie, maar eerder te vermeerder.

\section{STRATEGIE}

Om bostaande doelstelling te realiseer, sal aan die volgende sake aandag gegee word:

- 'n besinning oor probleme ten opsigte van die tweede erediens op 'n Sondag;

- 'n beskrywing van die Bybelse Sondagviering om te probeer vasstel wat in die lig van die Woord op Sondag van 'n gelowige en van die kerk verwag word;

- 'n beskrywing van die verloop van die tweede erediens om te bepaal in watter mate ' $n$ tweede erediens op die Sondag prinsipieel noodsaaklik is en of dit noodwendig in die aand moet plaasvind;

- die formulering en die evaluering van moontlike oplossings.

3.1 Probleme ten opsigte van die tweede erediens op die Sondag

Dit is noodsaaklik dat gevra sal word na die redes waarom die tweede erediens swak bygewoon word. Baie van die genoemde redes is dieselfde waarom die oggend-erediens ook nie bygewoon word nie.

\subsubsection{Die bestaande situasie}

Baie van die gemeentes se tweede erediens word swak bygewoon. Die lidmate wat nog die tweede diens bywoon, beleef hierdie klein aantal baie negatief en begin dan self wegbly. As gevolg van die swak bywoning van die tweede diens begin predikante om hierdie diens as minder belangrik te beskou en skeep gevolglik hulle voorbe- 
reiding af. Die lidmate voel hierdie swakker beplanning en voorbereiding aan en bly gevolglik weg.

\subsubsection{Algemene kritiek teen die erediens}

Die kritiek wat teen die erediens uitgespreek word, loop oor 'n baie bree linie. Een van die kernpunte is die feit dat die moderne mens sogenaamd nie meer deur die erediens aansgepreek word nie. Die corsake vir hierdie onaangesprokenheid word in baie dele van die erediens gesoek en gevind.

\subsubsection{Die moderne mens se beskouing ten opsigte van God en die kerk}

Die kerk leef in 'n wêreld waar die heidendom toeneem. God is nie meer die middelpunt nie, maar die mens. Dit gaan nie meer om die eer wat aan God gebring moet word nie, maar die mens se behoeftes wat bevredig moet word. Omdat God vir die mens dood is, bestaan die kerk ook nie vir die mens nie.

Daar is baie mense wat sê hulle glo in God, maar nie aan die kerk nie. Die kerk is vir hulle 'n algehele menslike uitvindsel. Hulle sê hulle het God nodig, maar nie die kerk met sy erediens nie.

\subsubsection{Die aanddiens is 'n blote replika van die oggenddiens}

Beide Barnard en Dressel is van mening dat die swak bywoning van die tweede diens veral te wyte is aan die feit dat hierdie diens se vorm dieselfde is as diê van die eerste diens. 'Die kerk self kan die aanddiens devalueer waar daaraan nie 'n eie karakter gegee word nie. 'n Verbeeldinglose inrigting van die aanddiens of waar dit slegs 'n swak-beplande en doellose replika van die oggenddiens is, is die sterkste faktor wat die ondermyning daarvan bewerk. So 'n diens sal nie vir lidmate sinvol wees of hulle daarheen aantrek nie' (Barnard 1986:3). Dressel haal Lekkerkerker aan wat gesê het: 'Een kerk, die van de Zondagavonddienst een herhaling maakt van de Zondagmorgendienst, is bezig de grond onder deze avonddienst weg te graven' (Lekkerkerker, in Dressel 1987:69).

\subsubsection{Minder vrye tyd}

In teenstelling met die verlede het baie mense vandag minder vrye tyd. In baie huisgesinne, veral waar beide ouers werk, is die gesin net op Sondae beskikbaar vir mekaar. Dit bring mee dat baie huisgesinne Sondagoggende saam die erediens bywoon, maar die res van die Sondag vir mekaar beskikbaar wil wees. Omdat dit die gesin se enigste vrye tyd is, is dit ook die enigste tyd wat hulle vir familie en vriende kan gaan kuier. 


\subsubsection{Erediens en media}

Die radio en veral die televisie met goeie luister en kykprogramme het 'n magtige konkurrent vir die tweede diens geword.

Waar die aanddiens nie iets bied wat anders is as die radio en televisie nie en waar mense nie iets ontvang wat hulle nêrens anders kan ontvang nie, soos die gevoel van geborgenheid en die selfbelewing, daar is dit begryplik dat hulle eerder na die programme van die radio en die televisie sal luister en kyk (Barnard 1978:3).

\subsubsection{Beskouing oor twee eredienste op 'n Sondag}

Baie lidmate (dikwels getroue lidmate) oordeel dat een erediens op 'n Sondag genoeg vir 'n mens se geloofslewe is. Baie predikante worstel weer met die probleem dat hulle nie twee preke vir een Sondag kan voorberei nie.

\subsubsection{Swak voorbeeld}

Ten opsigte van die bywoning van die tweede erediens stel ampsdraers en leiersfigure en hulle huisgesinne nie altyd die regte voorbeeld nie. In baie gemeentes gebeur dit dat die meeste lede van die kerkraad en die kategete nie die tweede diens bywoon nie.

\subsubsection{Tweede erediens prinsipieel moeilik verantwoord}

Uit die Bybelse en historiese gegewens kan maklik afgelei word dat die gemeente op 'n Sondag 'n erediens moet hou, maar nie sonder meer hoeveel eredienste gehou moet word nie. As uit die vierde gebod afgelei word dat die hele Sondag vir die diens van God afgesonder moet word, beteken dit nie noodwendig eredienste nie.

Selfs persone wat die tweede erediens bepleit, kry dit baie moeilik verwoord soos uit onderstaande aanhaling blyk:

Aangesien die oggenddiens die karakter bepaal van die res van die Sondag en die hele week, as die tydseenheid van ons lewe, is die tweede, die derde, of die soveelste diens op Sondag of ander dae, nie in alle gevalle 'n prinsipiële moet soos die eerste nie. Merkwaardig dat die erediens die fees van die gemeente genoem word. Dit gaan nie in die eerste plek om die aantal eredienste per Sondag nie, maar om die erediens...Hoewel Calyyn soms daagliks gepreek het en Sondae meer as een keer, vereis hy na aanleiding van die vierde gebod nérens 'n spesifieke tweede diens nie. So vind ons dit ook in die belydenisskrifte op grond van die Skrifgegewens, dat daar gespreek word van die "vergadering van die volk van God" en "dat die kerkdiens of die prediking onderhou moet word" ...Per slot van sake is die begrip tweede 
erediens 'n relatiewe begrip. Met tweede erediens word soms prakties eerste bywoning bedoel en soms tweede bywoning van die erediens. In die eerste geval is die tweede erediens uit 'n geloofspunt gesien 'n prinsipiële noodsaaklikheid; in die tweede geval 'n praktiese nuttigheid.

(Van der Westhuizen 1976:87-88)

\subsubsection{Die Bybel vereis nie sonder meer 'n aanddiens nie}

Baie predikante en lidmate sien die erediens spesifiek in die aand as die Bybels-bepaalde weg. Daar word dan veral verwys na Jesus wat 'n paar keer saam met sy dissipels in die aand vergader het, Paulus wat eenkeer in die aand gepreek en Nagmaal bedien het en die vroeë Christene wat in die aand kerk gehou het. Hier word vergeet dat die aand vir die Jode besondere betekenis as dagbegin gehad het en verder dat die Sondag in die vroegste tyd nog nie die amptelik rusdag was nie. Die mense moes op die Sondag werk en kon gevolglik net in die aand erediens hou. 'Skriftuurlik gesien kan daar dus hoogstens gesé word dat daar op die Sondag in 'n erediens byeengekom moet word. Tyd en aantal word nêrens voorgeskryf nie' (Dreyer 1990: 1).

Sosiologiese en ander faktore is dikwels die oorsaak dat die aand in bepaalde gebiede en tye juis die mees ongeleë tyd vir die erediens is. Vanweë afstand, ouderdom, klein kindertjies en weersomstandighede sou dit vir baie mense meer geleë wees om die erediens op 'n ander tyd as in die aand te hou.

\subsubsection{Eenvormige Sondagviering landswyd}

In die kerk word gewoonlik 'n baie groot premie op eenvormigheid geplaas. In die Nederduitsch Hervormde Kerk van Afrika word daarom van al die gemeentes verwag om twee eredienste op die Sondag te hou en bestaan die ongeskrewe verwagting dat die tweede erediens in die aand moet wees.

Die handhawing van die standpunt beteken doodgewoon dat daar nie rekening gehou word met demografiese, historiese, sosiologiese en selfs prinsipiële gegewens nie.

\subsubsection{Christus se opdrag aan die kerk}

In die kerk word die klem dikwels s6 op die erediens gelê dat die gedagte verkeerdelik ontstaan dat om erediens te hou, die enigste taak en roeping van die kerk in die wêreld is. Daar is lidmate wat dink as hulle die eredienste van die gemeente bywoon, hoef hulle by niks anders in die gemeente betrokke te wees nie. Daar is ook predikante wat dink as hulle die erediens gehou het, hulle nie veel meer in die gemeente hoef te doen nie. 
Die erediens is die belangrikste gebeurtenis in die lewe van 'n gemeente en met die prediking as middelpunt die belangrikste werk van die predikant.

Christus se opdrag aan sy kerk is egter baie breër as net die hou van eredienste. Die sentrale opdrag van Christus aan sy kerk tref ons in Matteus 28:19 en Handelinge 1:8 aan. Die kerk moet met doop en leer mense tot dissipels van Jesus Christus maak. Dit impliseer die begeleiding van mense om in 'n persoonlike verhouding met Jesus Christus te staan. Volgens Firet word mense volgelinge van Jesus Christus deur die kerugma, die aankondiging - die prediking van Jesus Christus waarvan die doop 'n deel is. Hierdie dissipelskap hou egter ook in dat die persoon wat reeds tot die geloof gekom het, dieper en omvattender in die waarheid ingelei moet word. Deur die onderrig moet die heilsgebeure nader ontvou word. Die Skrif moet geopen en verklaar word sodat daaruit aangetoon kan word dat Jesus die Here is. Die sin en die konsekwensies van die kerugma moet aangetoon word en uitgespel word vir die lewe.

De didache richt zich op de totaliteit van het levenen op alle aspekten ervan. Zij kan geen ethisch onderricht zijn, zij kan ook niet leerstellig onderricht zijn. Dergelijke onderscheidingen schieten tekort en doen ook geen recht aan de nieuwtestamentiesche martyria, waarin het etische niet naast het leerstellige staat. De didache is "Glaubenshilfe als Lebenshilfe", maar men zou ook tegelijk moeten zeggen: "Lebenshilfe als Glaubenshilfe."

(Firet 1977:90)

Hierdie besondere dissipels maak van mense geskied in die kerk en deur die kerk langs die gewone kanale van prediking, kategese, pastorale sorg, evangelisasie en sending. Malan Nel het aangetoon dat hierdie werk eers tot sy volle reg kom deur aktiewe gemeentebou (Nel 1986:55).

Volgens H J C Pieterse vind die bediening in baie gemeentes van die kerk op 'n eensydige wyse plaas. Volgens hom moet die gemeentelike aktiwiteite deurlopend aan die 'normatief teologiese begrippe van kerugma, koinonia en diakonia getoets word' (Pieterse 1990:23). Tradisioneel word hierdie drieledige funksie van die kerk weer verder onderverdeel. Die kerugmatiese word verdeel in die aktiwiteite van prediking, onderrig, pastorale versorging, evangelisasie en sending. As Firet se beskouing van die didache en Malan Nel se opvatting van gemeentebou, met sy besondere gerigtheid op die toerusting van lidmate vir hulle dienswerk in die wêreld, in die oog gehou word, lê die hedendaagse kerk se tekortkoming in 'n baie groot mate in die rigting van die verwaarlosing van voortgesette Bybelse onderrig aan volwassenes. Hierdie leemte is na die reformasie aangevul met Kategismusprediking in die vorm van onderrig. 
Die besondere aard van die onderrig (Kruger 1980) en die mens tot wie die onderrig gerig is, laat tereg die vraag ontstaan of sinvolle doelgerigte Bybelse onderrig in 'n gewone erediens ten volle tot sy reg kan kom?

\subsection{Sondagviering}

Ignatius, biskop van Antiogië $110 \mathrm{n}$ C, Barnabas $100 \mathrm{n}$ C, Irenaeus $150 \mathrm{n}$ C en Origines $185 \mathrm{n} \mathrm{C}$, bevestig dat dit in die eerste twee eeue die algemene gebruik was dat die Christene op die eerste dag van die week byeen gekom het (Du Toit 1969:17).

Vir die kerk is dit nie net belangrik dat 'n sekere dag as kerk- en rusdag afgesonder word nie, maar dat hierdie dag ook op die regte wyse gevier word. In die lig van ons tema sal die vraag gevra moet word: Eis die Skrif dat daar twee eredienste op Sondag gehou word?

Die kerk het deur die eeue geoordeel dat Jesus Christus nie die vierde gebod afgeskaf het nie, maar vervul het. Dit beteken dat die wese daarvan nog vir die Christen geld.

\subsubsection{Wat is die wese van die vierde gebod?}

Heiliging is die eerste saak wat in die vierde gebod na vore kom. Heiliging beteken in die spraakgebruik van die Ou Testament: uitgesonder van die gewone alledaagse lewe en gebruik en om dit in die besonder af te sonder vir God en sy diens. Engelbrecht oordeel dat die Sondag daarom in die eerste plek gegee is tot diens aan God en daarom moet dit bestaan uit stigting, lering en opvoeding van die gemeente (Engelbrecht $\mathrm{s} \mathrm{j}: 30$ ). Die motivering tot onderhouding van die vierde gebod toon duidelik die sentraliteit van God en sy diens op hierdie dag aan. Hieruit kan afgelei word dat die rusdag gegee is om dit te oordink dat God die mens se enigste verlosser, skepper en onderhouer is. In die lig van die verbond is 'die vierde gebod net soos die ander gebooie wet en evangelie. Sabbatsevangelie - God het jou lief; Sabbatswet - jy moet God lief hê' (Kuyper 1982:3).

Die tweede hoofmoment wat in die vierde gebod na vore kom is liggaamlike rus. Die woord sjabath beteken juis om klaar te wees met iets. God wat die mens se beperkte vermoëns ken, het van die begin af bepaal dat die mens 'n terugkerende rusperiode sal hê.

Jesus Christus het die wese van die vierde gebod gehandhaaf. Vir hom was dit 'n Godgegewe dag om deur die mens geniet te word en nie 'n dag van sware pligpleging nie (Mark 3:27). Verder was dit vir Jesus 'n dag van erediens, onderrig, liggaamlike rus en ontferming oor mense wat in nood verkeer (Luk 4:6; Matt 12:1; Luk 13:14). 
Die eerste Christene het die rusdag benut vir Woordverkondiging, Nagmaalbediening en algemene kerkwerk (Hand 20:7; 1 Kor 16:2). Die Reformatore het in 'n baie groot mate die Sondag losgemaak van die streng Joodse sabbatsbeskouing en het hoofsaaklik die wese van die vierde gebod gehandhaaf.

Nagel (1962:193) sê die volgende:

Luther sieht im Kleinen und Großen Katechismus den Inhalt des Sontags darin, daß wir Gottes Wort heilig halten, gern hören und lernen. Auch die Confessio Augustana bleibt im 28 Artikel (57-64) eindeutig auf dieser Linie, ebenso die Kirchenordnungen des 16 Jhs nicht minder der Heidelberger Katechismus.

Die Heidelbergse Kategismus sien die Sondag veral as 'n dag in diens van God. Hierdie diens bestaan in die besonder uit 'Woordbediening en godsdiensonderrig'. Wat bedoel die Kategismus met 'Woordbediening en godsdiensonderrig"? Die meeste vertalings het dit vertaal met 'das Predigamp und Schulen' (Ministerium Evangeli et Scholae) (Oberholzer 1985:138). Die begrip 'skole' is verskillend geïnterpreteer. Dit is die teologiese opleiding van predikante (Dijk s j:169). Haitjema sien dit breër as net die teologiese opleiding. Vir hom is dit die 'gewone lager onderwijs en het voortgezet onderwijs' (Haitjema 1962:253). Veldkamp se verklaring word deur die meeste kommentatore van die Heidelbergse Kategismus aanvaar. 'Bedoeld is dus: alles wat met het kerklijkleven samenhangt en er uit voortvloeit: Zending, evangelisatie, diaconie en soveel meer. Dat moet allemaal onderhouden' (Veldkamp, II s j:174).

Opsommend kan die Sondag beskryf word as 'n dag van diens: diens aan God, diens aan ons medemens en diens aan onsself. Die klem sal egter altyd op die diens aan God moet val.

Die diens van God op die Sondag bestaan uit erediensbywoning, geestelike toerusting, die uitdra van die evangelie na ander mense en ander kerkwerk.

Die diens aan die naaste op Sondag bestaan uit die verkondiging van die evangelie en barmhartigheidsdiens.

Die diens aan onsself op Sondag bestaan uit die oorpeinsing van die Woord van God en liggaamlike rus.

Diens op Sondag beteken daarom nie net diens in die vorm van 'n erediens nie.

\subsection{Bybelse gegewens oor die erediens}

In die Ou Testament is daar geen vaste voorskrif wanneer en hoe dikwels die erediens moet plaasvind nie. Die Ou Testament adem 'n gees dat die gelowige met sy 
hele lewe elke dag in diens van God staan. Die verbond tussen God en die volk Israel het gelei tot 'n besondere verhouding tussen God en sy volk. Hierdie verhouding het veral tot uitdrukking gekom in die kultiese gemeenskap (Van der Merwe 1988:16).

Behalwe hierdie daaglikse lewe in diens van God, het die gelowiges gereeld by die tempel saamgekom. In die na-ballingskapperiode was dit waarskynlik die vaste gebruik om daagliks by die tempel byeen te kom. Die kern van die tempeldiens was die offerdiens. Gedurende die ballingskap kon die tempeldiens nie voortgesit word nie. Dit het daartoe gelei dat die priesters begin het om die Woord van die Here te verkondig op plekke weg van die tempel. Van der Westhuizen oordeel dat hierdie Woorddienskarakter die sinagogale-erediens na vore gebring het (Van der Westhuizen 1975:126).

Die aand het by die Israeliete ten opsigte van religieuse aktiwiteite 'n besondere plek ingeneem. Die paaslam is teen laatmiddag geslag. In dieselfde nag is dit voorberei en geëet. Die pasga is daarom 'by uitstek 'n aand of nagfees' (Dressel 1987: 16). Baie van die offers is in die oggend en in die aand gebring (1 Kon 18:36; Esra 9:4-6 en Eksodus 27:20). Die gebed is ook in die besonder 'n saak vir die aand (Psalm 1:2; 22:3; 42:9; 92:2, 3; 141:1, 2). Die Shema (belydenis) is twee keer per dag opgesê - in die oggend en in die aand (Deut 6:4-9, 13-21; Num 15:37-41). Dit is veral godsdienstige seremonies wat te doen het met ligte wat in die aand 'n besondere rol gespeel het (Eksodus 25:31-40; 30:8; 27:20). Die Israeliete het besondere betekenis geheg aan die aand omdat hulle maand en jaartelling gekoppel was aan die maan en nie aan die son nie. Omdat die Joodse nuwe maand met nuwe maan begin, begin hulle jaar, week en dag ook in die aand.

Die sinagogale erediens wat in die ballingskapperiode ontstaan het, het 'n groot invloed op die Christelike erediens uitgeoefen. In die sinagoge was daar daagliks vier gebedstye: in die môre, die middag, die aand en laatnag. Laasgenoemde twee het geleidelik saamgesmelt.

Die byeenkomste aan die begin en die einde van die Sabbat het groter klem gekry as die gewone daaglikse byeenkomste, dit wil se die dienste wat gehou is op die Vrydag en die Saterdagaand.

Jesus en sy dissipels, self Jode, het die bestaande Joodse gebruike nagevolg. In Lukas 4:16 lees ons dat dit Jesus se gewoonte was om op die Sabbatdag die sinagoge te besoek. Paulus het hierdie gebruik gehandhaaf (Hand 17:3, 10). Die Joodse Christene het aanvanklik vasgehou aan die daaglikse opgaan na die tempel.

Toe daar verset kom van die kant van die Jode, het die Joodse Christene opgehou met die tempeldiens en op ander plekke saamgekom. Die nie-Joodse Christene het uit die staanspoor nie by die tempeldiens ingeskakel nie. 
Geleidelik het die eerste dag van die week vir die Christene hulle kerkdag geword. Lee is van oordeel dat dit spoedig in Troas 'n vaste gebruik geword het om op die Sondagnag byeen te kom vir erediens: 'It may be regarded as definitely established that the congregation at Troas met at a regular place of worship on Sunday each week to hear the preaching of the gospel and sometimes to break bread... demarcated from midnight to midnight (Lee, in Dressel 1987:24).

In die diskoers rondom die erediens is dit van die allergrootste belang om te let op die feit dat daar in die Nuwe Testament besondere klem gelê word op die opdrag om die evangelie van Jesus Christus tydig en ontydig te verkondig (2 Tim 4:2) (Van Wyk 1975:140). Die opdrag is nie dat dit noodwendig in die erediens moet geskied nie.

Gevolgtrekkings:

- Beide die Ou en Nuwe Testament vermeld dat gereelde byeenkomste van die gemeente op die rusdag plaasgevind het.

- Die aantal en vorm van hierdie byeenkomste word nie voorgeskryf nie. Nêrens is sprake van 'n wet ten opsigte van 'n tweede erediens op die rusdag nie.

- Die aandbyeenkoms het slegs 'n belangrike plek ingeneem, omdat die Joodse dag, maand en jaar in die aand begin het en omdat die eerste Christene gedurende die dag moes werk.

- Die byeenkomste het hoofsaaklik bestaan uit die bediening van die Woord en antwoord op die Woord.

\subsection{Die geskiedenis van die tweede erediens}

In die vroeë Christelike kerk is gereeld eredienste gehou. Hierdie eredienste het wat aantal en vorm betref van land tot land verskil. In die vroeë kerk is daar sprake van byeenkomste in die oggend en die aand. Ignatius maak in ongeveer $100 \mathrm{n} \mathrm{C}$ melding van die agape wat in die aand gehou is. Hippolytus getuig teen ongeveer $200 \mathrm{n} \mathrm{C}$ dat die agape Sondagaand gehou is en die Nagmaal Sondagoggend.

Geleidelik is die klem van die aanderediens na die oggenderediens verskuif (Van der Westhuizen 1975). Hierdie verskuiwing hang saam met die feit dat die Christene die vroeë oggend van die verskyningsdag van die opgestane Heer as 'n besondere herdenkingstyd beskou het (Barnard 1964:212).

Naas die besondere eredienstye het dit steeds gebruik gebly om ook op ander dae vir godsdienstige aktiwiteite byeen te kom. Dit was veral vaste gebedstye wat algemene gebruik geword het.

In $520 \mathrm{n} \mathrm{C}$ het Benedictus van Nursia sy kloosterreëls opgestel. Uit hierdie reëls het die Roomse gebedeboek en eredienstereëls voortgevloei. Die daaglikse twee hoofdienste was die môre en die aandgebed. Hierdie Vesperdiens het geleide- 
lik sy gemeentelike karakter verloor. Algaande het dit 'n diens geword waar slegs die geestelikes bid en die gemeente toeskouers is. Volgens Barnard het hierdie 'Vesper' in die vroeë kerk spoedig tot 'n aanddiens ontwikkel en het eers weer teen die einde van die Middeleeue net 'n gebedsdiens geword (Barnard 1964:243).

Die aantal gebedstye in die Rooms-Katolieke Kerk is geweldig uitgebrei. In die meeste gevalle het dit verword tot gebede wat slegs deur geestelikes in kloosters gebid is. Daar die hoofdiens by die Rooms-Katolieke hoofsaaklik bediening van die Nagmaal aan die geestelikes was, was daar eintlik van die erediens op Sondag in die volle sin van die woord nie meer sprake nie.

Luther het die gebruik om die gemeente vir gebed te laat vergader, behou. Hy het die aantal gebedstye verminder tot een soggens en een saans. Hierdie geleenthede is ook benut om die gemeente se geloof op te bou deur prediking of die Skrifuitleg. In die Lutherse Kerk het die oggenddiens later die 'Hauptgottesdienst' geword en hiernaas bestaan die 'Nebengottesdienst' (Dressel 1987:38).

Zwingli het Sondageredienste om 08:00 en 16:00 gehou; die middagdiens gewoonlik vir die kinders.

Bucer wou soveel dienste as moontlik op 'n Sondag hou. Hy het die gemeente soms tot ses keer laat byeenkom. Sang is veral gebruik om die eredienste aantreklik te maak. Slegs die oggenddiens het by Bucer 'n vaste liturgie gehad en vir die ander dienste was daar 'n mate van vryheid.

Net soos Zwingli het Calvyn die gebedsdienste op Sondag met preekdienste vervang. In die meeste kerke wat Calvyn se voorbeeld nagevolg het, is die gebedsdienste met familiegebede in die oggend en die aand vervang, en weeklikse byeenkomste is gehou om die Bybel te bestudeer. Kategese is op 'n Sondagmiddag gehou. Calvyn wou aanvanklik vier eredienste op 'n Sondag hou, maar het dit later tot twee gereduseer. By feitlik al die reformatore het dit gebruik geword om die tweede erediens vir besondere onderrig van die gemeente en veral die kinders aan te wend: 'Teen die agtergrond van Bybelonkunde sowel by volwassenes as jeug vanweë die Roomse eentalige kerktaal en leke kerkvolk, was dit in die besonder nodig om die hervormde kerkvolk in hulle eie taal toe te rus in leerdienste. Die tweede diens is deur die hervormers hiervoor ingerig' (Van der Westhuizen 1976:77).

In Nederland het dit onder andere vaste gebruik geword om in die middag uit die Kategismus te preek. 'Die nasionale Sinode van Den Haag het in 1586 hierdie besluit vasgelê vir die hele Nederland en dit is in 1618/19 te Dordrecht bekragtig' (Van Zyl 1987:18).

Hierdie tweede erediens op die Sondag se liturgie het nie noodwendig ooreengestem met dié van die eerste diens nie. Ten opsigte van A Lasco se Forma ac Ratio sê Nichols: 'The service after noon on the Lord's Day, first of all, featured a syste- 
matic exposition of the Cathechism, for which room was made by a shortening of the sermon. The Commandments, confession and absolution, and Creed were also ommitted. In this way a regular program of theological instruction was built into the weekly schedule' (Nichols, in Dressel 1978:49).

Uit die voorrede tot die Heidelbergse Kategismus, blyk dit dat die tweede erediens, waar die Kategismus gepreek is, 'n ander liturgie gehad het as die eerste erediens. Die tweede erediens was didakties van aard. Die vorm was ook spontaner deurdat vrae aan die lidmate gevra is waarop hulle reageer het.

Verder moet elke Sondagmiddag op 'n uur wat plaaslik pas, kategismusprediking gehou word op die volgende wyse: Na die gesange moet die kerklike ampsdraer die Onse Vader bid en God aanroep om die regte verstaan van sy Woord. Daarna moet hy die Tien Gebooie duidelik aan die gemeente voorlees. Dan moet hy dié wat die vrae waaroor reeds gepreek is, nog nie kon leer nie, ondervra en stelselmatig eers 'n tyd lank op die teks en daarna algaande op die vraagstuk afstuur. Daarop laat hy etlike van die jongmense 'n bepaalde getal vrae in die Kategismus opsê wat in die voorafgaande prediking verklaar is en veral dié wat in die volgende prediking verklaar sal word, vrae wat hulle vantevore in die skool of tuis geleer het. (Vir dié doel is die Kategismus in Sondae verdeel). Wanneer dié vrae so in teenwoordigheid van die gemeente deur etlike jongmense opgesê is, moet die ampsdraer 'n aantal van die volgende vrae eenvoudig en kortliks verklaar en uitlê, sodat hy die Kategismus minstens eenmaal per jaar deurpreek.

(Oberholzer 1985:21)

Die omstandighede in Nederland tydens die kerkhervorming en die tydperk daarna, word deur A D Pont soos volg beskryf: 'Die vaste gebruik in die Nederlandse kerk, nadat die Hervorming in Nederland geseëvier het, wat die aantal godsdiens-oefeninge betref, was dat daar minstens drie godsdiensoefeninge per Sondag gehou is, terwyl daar buitendien twee godsdiens-oefeninge, in die oggend én in die middag op weeksdae gehou is' (Pont, in Van Wyk 1975:141, 142).

Die bekering van die Wesley-broers in 1738 het gelei tot die ontstaan van die Metodiste-kerk. Nadat John Wesley weggebreek het van die Anglikaanse kerk, het hy begin om op Sondae aanddienste te hou (Barnard 1986:10). Hierdie aanddienste is as preekdienste ingerig. Die sogenaamde revival preek met 'n sterk oproep tot bekering het die middelpunt van die erediens gevorm en daarom het dit geleidelik evangelisasiedienste geword ( $\mathrm{d}$ w s dienste met 'n ander karakter as die gewone erediens op Sondag.) 
Met die koms van Jan van Riebeeck is die eredienspatroon soos dit vasgelê is op die Sinode van Dordtrecht in 1618/1619, net so van Nederland na Suid-Afrika oorgeplaas (Barnard 1981:377).

Die eerste vyftien jaar was daar nie 'n predikant aan die Kaap nie. Willem Wijlant, 'n sieketrooster, het die godsdiensoefeninge waargeneem. Daar was aanvanklik net een erediens op 'n Sondag wat soos volg afgewissel is: Een Sondag het hy 'n preek oor 'n Bybelteks voorgelees èn die volgende Sondag 'n verklaring oor die Kategismus.

Nadat predikante meer beskikbaar geword het, het dit algemene gebruik geword om twee eredienste op 'n Sondag te hou. Die Nederlandse gebruik is oorgeneem en die middagdiens is veral gebruik as leerdiens en diens waartydens die kinders gedoop is (Dressel 1979:113).

Met die Groot Trek het die Voortrekkers aan hulle kerklike gebruike probeer vashou. Uit die aard van die saak kon daar vanweè die predikanttekort, nie altyd daarin geslaag word om twee eredienste - soms nie eers een - op 'n Sondag te hou nie.

Op kerklike vergaderings is nie baie aandag aan liturgiese sake gegee nie. Eers so laat as 1973 het die Nederduitsch Hervomde Kerk van Afrika besluit om indringend aandag te gee aan die tweede erediens op die Sondag. Hierdie besluit is geneem omdat die tweede erediens op Sondag volgens die ringsverslae baie swak bygewoon word.

As studiekommissie is drr D J C van Wyk en $\mathrm{H} \mathrm{G}$ van der Westhuizen benoem. Op grond van bogenoemde doktore se studiestukke besluit die Algemene Kerkvergadering van 1976 (Notule Algemene Kerkvergadering 1976:265-266):

* Die wenslikheid en noodsaaklikheid van 'n tweede erediens elke Sondag word deur die vergadering beklemtoon.

* Die vergadering dra aan alle kerkrade op om in die lig van die studiestukke van drr Van Wyk en Van der Westhuizen opnuut ernstig oor 'n tweede erediens te besin in die gevalle waar dit nie gehou word nie en om indien dit prakties moontlik sou wees gereeld 'n tweede erediens te hou.

- Die vergadering dra aan ringsvergaderings op om hulle van die omstandighede van die ringsgemeentes te vergewis en opsig oor die hou van 'n tweede erediens in die gemeentes uit te oefen.

- Bepaling 5.b.i. word gewysig deur die woord 'Sondae' te vervang met die woord 'elke Sondag'.

- Dat aan die Raad vir Prediking, Erediens en Kerkbou opdrag gegee word om 'n studie te makk oor die bestaan van die verskil in karakter tussen die twee eredienste op Sondae, al dan nie. 
In die Nederduitse Gereformeerde Kerk het die geskiedenis van die tweede erediens op die Sondag feitlik dieselfde verloop as in die Nederduitsch Hervormde Kerk van Afrika. Die enigste wesenlike verskil is dat daar op 'n baie vroeër stadium - sedert 1953 - reeds met 'n ondersoek na die vormgewing van die tweede erediens begin is. In 1961 rapporteer die kommissie 'Dit blyk 'n ingewikkelde aangeleentheid te wees om uit te vind wat die karakter van die tweede diens behoort te wees, sodat die kommissie hiermee nog nie gereed is nie' (Dressel 1987:64). In 1978 gee die Algmene Sinode breë riglyne vir die tweede diens, maar neem eers in 1986 besluite ten opsigte van dié erediens. Hierdie besluite hou basies in dat die tweede erediens in die aand gehandhaaf word, maar dat sy vormgewing verskil van die eerste diens (Notule Algemene Sinode van die Nederduitse Gereformeerde Kerk 1986: 625).

In die Gereformeerde Kerke in Suid-Afrika het die tweede erediens as 'n 'egte leerdiens' behoue gebly (Dressel 1987:72). Op die platteland bestaan die gebruik dat hierdie tweede diens in die oggend direk na die eerste erediens gehou word.

Opsommend kan die volgende punte voorgehou word:

- Deur die eeue heen is daar in die meeste kerke meer as een erediens of byeenkoms van die gemeente op die Sondag gehou; nie noodwendig altyd in die aand nie, maar op verskillende tye, afhangende van die omstandighede van die gemeente.

* Die tweede gemeentelike Sondagbyeenkoms verskil gewoonlik in vormgewing van die eerste een.

3.5 Voorstelle met die oog op die tweede erediens op die Sondag

In die moderne tyd het 'n groot hoeveelheid nuwe vorme van die erediens na vore gekom. Baie van hierdie vorme is hoofsaaklik geskep met die oog op groter betrokkenheid, veral wat die tweede erediens betref.

Die volgende is sommige van die nuwe erediensvorme wat voorgestel word: (Vir meer volledige gegewens in verband met hierdie eredienste, vgl Dressel 1987: 90-118; Beukes 1987:4-8).

\subsubsection{Die tweede diens in die vorm van 'n bespreking}

Die preek en sekere elemente van die erediens word behou. Op 'n baie kort preek volg 'n bespreking wat een van die volgende moontlikhede inhou: bespreking in die hele groep aan die hand van bepaalde vrae; kleingroepbespreking en daarna terugvoering en bespreking in die hele groep; bespreking gedurende die week in wyksverband of in verskillende afdelings van die kerk se werksaamhede, soos byvoorbeeld die jeug- en die vroue-aksies. 


\subsubsection{Bybelstudiegroepe}

Die aanddiens word vervang met Bybelstudiegroepe wat wyksgewys of volgens die gemeente se verskillende werkgroepe plaasvind (Louw 1980:154-155).

\subsubsection{Die tweede diens as leerdiens}

In die moderne tyd word die onderrigdiens weer vanuit verskillende oorde bepleit. Die algemene gedagtegang is stellig dat die vormgewing anders sal wees as die eerste diens. Die leerdiens is noodsaaklik, maar dan in die vorm van die moderne leergeleenthede. 'Want de vormgewing van de leerdienst moet zo eenvoudig mogelink zijn, moet ruimte laten voor velen mogelijkheden juist omdat hij vele gestalten kan vertonen' (Lekkerkerker, in Dressel 1987:94-95).

\subsubsection{Die tweede diens in die vorm van toenusting}

Die tweede diens kan in die besonder benut word om die gelowiges toe te rus vir hulle dienswerk in die wêreld. Hierdie toerusting kan geskied aan die hand van 'n bepaalde tema wat betrekking het op die hele gemeente of dit kan toegespits wees op ' $n$ bepaalde groep van die gemeente.

\subsubsection{Ekumeniese en gesamentlike dienste}

Dit is eredienste waar die kerk- en gemeenteverband nie in ag geneem word nie en gesamentlik gereël word deur groepe met gemeenskaplike belange.

\subsubsection{Diakonaal-sosiaal dienste}

Dit is dienste wat gehou word met die oog op 'n bepaalde aksie wat verrig moet word. Die inhoud van die aksie kom tydens die diens aan die orde en na afloop daarvan word die praktiese gegewens bespreek sodat die gemeente bepaalde aksies in die wêreld kan gaan verrig. In sekere kringe is hierdie dienste gebruik om bepaalde politieke ideale te verwesenlik.

\subsubsection{Ervaring- of emosionele eredienste}

Hier val die klem in 'n baie groot mate op die mens se emosionele ervaring. Deur middel van die media, - veral orkeste en ligte - word die mens met behulp van sang wat 'n lekker 'beat' het, emosioneel weggevoer. Hier is feitlik geen plek meer vir die verkondiging van die Woord nie. 


\subsubsection{Charismatiese eredienste}

Hierdie eredienste stem in 'n groot mate ooreen met die sogenaamde ervaringsdienste waar net meer geleentheid gegee word vir persoonlike getuies en die sogenaamde spreek in tale.

\subsubsection{Gebedsdienste}

Dressel toon aan dat die gebedsdiens - deur die eeue - veral in die aand voorgekom het en vandag nog in baie kerke in stand gehou word en selfs na reformatoriese kerke uitbrei (Dressel 1987:99-103).

\subsection{Die tweede diens as Sakramentsbedieninggeleentheid}

Die doop en die Nagmaal word in die aand in plaas van in die oggend bedien.

\subsubsection{Sangdienste}

Die erediens word so ingerig dat sang in verskillende vorme die iof van God verkondig. Hiermee gekombineerd kan Skriflesings plaasvind (die sogenaamde liturgiese diens).

\subsubsection{Opvoerings}

Die hele erediens word vervang met 'n uitbeelding van die bepaalde boodskap in toneel, musiek of konsertvorm. Veral die drama is besonder gewild. Dit is soms 'n 'lewende' opvoering waarin daar gebruik gemaak word van 'n video of films. Hierna kan 'n bespreking aan die hand van vooraf opgestelde vrae volg.

\subsection{Gevolgtrekking}

Die primêre probleem van die tweede erediens is volgens Dressel die feit dat die aanddiens 'n duplisering van die oggenddiens is. As oplossing beveel hy aan dat die aanddiens behou word, maar anders as die oggenddiens ingeklee word. Hy beveel die volgende alternatiewe eredienste vir die aand aan (Dressel 1990:128-140; 1987: 131-156):

- 'n erediens met die klem op die Nagmaal;

- 'n erediens met die klem op die wet, skuldbelydenis, geloofsbelydenis en preek;

- 'n erediens met die klem op lering;

- 'n erediens met die klem op gebed;

- 'n erediens met die klem op sang;

- 'n erediens met die klem op diens;

- 'n erediens met die klem op belydenis en getuienis;

- 'n erediens met die klem op koinonia; 
- 'n erediens met die volgende byeenkomste daarna: kerkkonsert, Bybelstudie, kerkjeugaksies of ander toerustingsgeleenthede.

Dressel beveel nie werklik 'n ander vorm vir die tweede erediens aan nie, maar voeg eintlik net bepaalde aktiwiteite na afloop van die erediens by. Dit is met ander woorde 'n erediens plus 'n Bybelstudie of 'n toerustingsgeleentheid ensovoorts. In 1986 het die Nederduits Gereformeerde Kerk na deeglike besinning besluit dat die tweede erediens (veral in die aand) gehandhaaf moet word. Omdat die tweede erediens 'n ander doel en kenmerke as die oggenddiens het, behoort dit ook 'n ander vorm te hê. 'Behalwe uitsonderings, mag die aanddiens nie maar net 'n replika, 'n doeblet van die oggenddiens wees nie' (Agenda Algemene Sinode NG Kerk 1986: 203).

Die volgende erediensvorme word deur die NG Kerk in 1989 vir die aanddiens aanvaar:

- Die aanddiens as 'n gewone erediens;

- Die aanddiens as volledige diens met Nagmaal;

- Die aanddiens met die klem op die leer;

- Die aanddiens met die klem op die gebed;

- Die aanddiens met die klem op die gesonge gebed - die lied;

- Die aanddiens met die klem op die groot werksaamhede van die kerk;

- Die aanddiens met die klem op belydenis en getuienis;

- Die aanddiens met die klem op samespreking;

- Die aanddiens met die klem op die onderlinge gemeenskap-koinonia.

Wat die vormgewing betref, word ruimte gelaat vir onderriggeleenthede met gebruikmaking van moderne onderrigtegnieke soos o a groepbesprekings en die benutting van elektroniese en ander media (Agenda Algemene Sinode van die NG Kerk 1986:203-206; Notule Algemene Sinode van die NG Kerk 1986:625). In die Nederduitsch Hervormde Kerk van Afrika is voortgaande besinning ten opsigte van die tweede erediens nog aan die gang. Na aanleiding van hierdie kerk se kommissie vir bedieningstrukture se aanbevelings, is in 1989 in 'beginsel', met die oog op verdere besinning, 'n aantal besluite geneem:

- Die Sondag moet optimaal tot verheerliking van God en tot opbou van die gemeente benut word.

" Om dit te bereik, moet minstens een erediens per Sondag gehou word. Kerkrade beplan die gemeenteprogram sodanig dat die predikant voldoende tyd kry vir voorbereiding vir die totale erediens, wat prediking en liturgie insluit. 
* In elke gemeente kan op Sondag, naas die moontlikheid van 'n tweede erediens, ook meerdere byeenkomste van die gemeente gehou word. Hierdie byeenkomste se tyd, plek en vorm word deur die kerkraad bepaal. Die tweede byeenkoms van die gemeente kan die volgende wees:

- 'n gewone erediens met of sonder sakramentbediening;

- 'n liturgiese diens;

- 'n Bybelstudiegeleentheid;

- 'n gesamentlike erediens van die Hervormde gemeentes in een dorp of ring;

- 'n byeenkoms met die klem op sang en musiek.

- Ringskommissies hou noulettend opsig oor elke gemeente se Sondagviering. Slegs in oorleg met die ringskommissie kan 'n gemeente minder as twee byeenkomste op 'n Sondag hou.

- Toerustingskursusse oor gewone en besondere eredienste vir ampsdraers en lidmate moet beplan word. Hierdie kursusse word vir predikante aangebied by die Fakulteit Teologie (UP) se Sentrum vir Voortgesette Tcologiese Toerusting (SVTT) en word as verpligtend vir hulle gestel. Op gemeentelike vlak word die kursusse aangebied deur die predikante en ander kundige persone (Notule Algemene Kerkvergadering 1989a:38).

\subsection{Evaluering vart wysigingsvoorstelle en eie standpuntinname}

Met die evaluering sal gepoog word om vas te hou aan die prinsipiële gegewens soos dit in die voorafgaande uiteensetting na vore gekom het. Baie van die voorstelle deur die charismatiese groepe is nie aanvaarbaar nie, omdat die bediening van die Woord op die agtergrond geskuif word en die konfessionele binding oorboord gegooi word soos by onder andere die sogenaamde ekumeniese dienste en die ervarings- of emosionele eredienste. Dressel het ook nie werklik daarin geslaag om sy teorieë in die praktyk te laat posvat nie. Hy bepleit dat die tweede erediens gehandhaaf moet word, maar in 'n ander vorm. Hy noem die nuwe vorm, maar deins terug as dit in die praktyk toegepas moet word. Hy kom net so ver as 'n tweede erediens met 'n plus daarby. Uiteindelik bly die tweede erediens se vorm dieselfde en die probleem van duplisering word nie opgelos nie.

Die rede waarom Dressel nie tot 'n nuwe vormgewing kan kom nie, is miskien vanweë die verkeerde uitgangspunt dat die gemeente twee eredienste op 'n Sondag moet hou en die tweede een juis in die aand moet plaasvind. Dressel se aanbeveling van 'n erediens plus 'n verdere byeenkoms in die aand, sal vanweë die tydsfaktor slegs geslaagd wees as dit net by uitsondering gehou word en nie 'n vaste gebruik in die gemeente word nie. Dressel se teorieë is deur die Nederduitse Gereformeerde Kerk op sy Algemene Sinode van 1986 ten volle deurgetrek na die praktyk. Hierdie 
kerk het daarin geslaag om die tweede erediens in 'n ander vorm te giet. Die vraag is of ons hier nog werklik met 'n erediens te doen het. Is dit nie hier die geval dat krampagtig aan die erediensinstelling vasgehou wil word, maar dat daar oor die inhoud geen bekommernis is nie.

Die vraag oor wat 'erediens' is, sal eers beantwoord moet word, voordat die gesprek verder kan gaan. Noordmans het in 1939 in sy stryd teen die Liturgiese beweging aangetoon dat die erediens niks anders kan wees nie as 'n gemeentelike byeenkoms waar die verkondiging van die Woord in die middelpunt staan (Hasselaar 1986:65). De Wet (1964) het die erediens soos volg beskryf:

'n Erediens is 'n onderlinge byeenkoms van 'n gemeente wat deur die kerkraad vasgestel is sodat die gemeente in die openbaar met God in ontmoeting kan tree. Met erediens word dan bedoel die totaliteit van woorde en handelinge wat tydens hierdie byeenkoms gespreek en voltrek word as versterking van die geloof wat die gemeente ontvang het en steeds weer opnuut moet ontvang. Hierdie woorde en handelinge word gespreek en voltrek tot vermeerdering van God se eer en tot nakoming van die diens wat Hy van die gelowige vra.

In hierdie definisie word die verkondiging van die Woord en die antwoord van die gemeente as die twee konstituerende elemente van die erediens beskryf. Aangesien die Woord op baie wyses verkondig kan word en die gemeente op baie wyses antwoord kan gee, is nadere beskrywing nodig. Indien die breë definisie van De Wet aanvaarbaar is, is eredienste wat hoofsaaklik bestaan uit Bybelstudie, voortgesette Bybelse onderrig, toerusting, gebede, sang, ensovoorts in klein groepe, groot groepe met behulp van verskillende media, ten volle aanvaarbaar. 'n Meer gespesifiseerde definisie van die erediens, laat die prentjie egter verander. Die volgende definisie behoort oorweeg te word: 'n Erediens is 'n Godgewilde geordende byeenkoms van 'n Christelike gemeente waar God deur Woord en Gees deur middel van Skriflesing, prediking en ander liturgiese elemente met die gemeente in ontmoeting tree om geloof te gee en te versterk en waar die gemeente deur gebed en ander elemente die heil wat hulle van God ontvang het, vier en dankbaar uitdrukking gee van hulle geloof in God. Uit hierdie definisie kom die volgende sake na vore ten opsigte van die erediens:

- 'n erediens is 'n ordelike byeenkoms van 'n Christelike gemeente;

- 'n erediens vind in die besonder plaas met die oog op stigting en versterking van geloof, die uitleef van die geloof en die viering van die heil wat deur Jesus Christus gekom het;

- 'n erediens bestaan uit ten minste Skriflesing, prediking en gebed. 
In die lig van bogenoemde kan die verskillende erediensvorme wat deur die Nederduitse Gereformeerde Kerk in 1986 aanvaar is, nie sondermeer beskou word as eredienste nie. Die weg wat die Nederduitse Gereformeerde Kerk ingeslaan het, is legitiem, maar daar behoort weggedoen te word met die krampagtige vasklou aan die begrip 'erediens' aangesien dít wat voorgestel word, nie werkiik 'n erediens is nie. Die aanbevelings van die Nederduitsch Hervormde Kerk van Afrika se bedieningstrukturekommissie verwoord in 'n groot mate die prinsipiële gegewens soos dit in hierdie studie na vore gekom het. Hierdie aanbevelings se aanvaarding behoort in 'n groot mate die probleme wat daar ten opsigte van die tweede erediens bestaan, te oorbrug. Puntsgewys sal die aanbevelings bespreek word:

- Die Sondag moet optimaal tot verheerliking van God benut word: Hier word nog geen uitspraak gemaak ten opsigte van die detail wat op die Sondag moet gebeur nie. Hier word net die breë beginsel gestel waaroor dit op die Sondag behoort te gaan, naamlik die eer van God en die opbou van die gemeente. In die breë beginsel ten opsigte van die Sondagviering word egter nie voorsiening gemaak vir die opbou van die individu se geloof, die ontferming oor die medemens in nood en die liggaamlike rus nie.

** Om dit te bereik, moet minstens een erediens per Sondag gehou word. Kerkrade beplan die gemeenteprogram sodanig dat die predikant voldoende tyd kry vir die voorbereiding van die totale erediens, wat prediking en liturgie insluit.

*: In elke gemeente kan op die Sondag, naas die moontlikheid van 'n tweede erediens, ook meerdere byeenkomste van die gemeente gehou word. Hierdie byeenkomste se tyd, plek en vorm word deur die kerkraad bepaal. Die tweede byeenkoms van die gemeente kan die volgende wees:

- 'n gewone erediens met of sonder sakramentbediening;

- 'n woord- en sangbyeenkoms;

- 'n Bybelstudie geleentheid;

- 'n gesamentlike erediens van Hervormde gemeentes in een dorp of ring;

- 'n byeenkoms met die klem op sang en musiek.

Met hierdie aanbeveling word van die gedagte om in al die gemeentes van die kerk twee eredienste, waarvan een in die aand is, afgesien. Naas die een erediens word ander byeenkomste van die gemeente as 'n moontlikheid aanbeveel:

* Minstens een erediens per Sondag is wat die Skrif prinsipieel aan ons voorskryf en wat tot op datum in die Kerkwet en Bepalings van die Nederduitsch Hervormde Kerk van Afrika bepaal word (Bep 83, Kerkwet 1989b: 44). 
** Die Kerkwet van die Nederduitsch Hervormde Kerk van Afrika het nog nooit bepaal dat die tweede byeenkoms van die gemeente in die aand moet plaasvind nie. Die bepaling lui: 'Die Kerkraad bepaal die aantal, plek en tyd van eredienste' (Bep 83, Kerkwet 1989b:44). Hierdie bepaling gee aan gemeentes die geleentheid om hulle gemeentelike aktiwiteite op Sondag in te rig volgens hulle eie omstandighede. In baie gemeentes, veral op die platteland sal dit baie geleë wees as die gemeente se erediens en ander byeenkomste in die oggend plaasvind. Die volgende sou 'n moontlikheid kon wees:

- 'n Erediens vind om 09:00 plaas;

- na die erediens begin die kinders met kategese en die belydende lidmate met 'n ander gemeentelike byeenkoms.

So ' $n$ viering van die Sondag kan meebring dat die godsdiensprogramme oor die media beter benut kan word en die Sondagaand kan dien as 'n gesinsaand en rusgeleentheid wat ' $n$ wesenlike deel van die Sondagviering is.

In hierdie aanbevelings word die moontlikheid gelaat dat die gemeente naas die erediens of nog ' $n$ erediens of 'n ander gemeentebyeenkoms kan hou.

"* Hierdie diversiteit is in ooreenstemming met die prinsipiële gegewens. Dit is belangrik om daarop te let dat die erediens nie al wyse is waarop God geloof gee en geëer word nie. God gee geloof deur verskillende verkondigingsgestaltes en Hy kan op baie maniere deur die mens geëer word.

** Deur die diverse moontlikhede word die probleem van duplisering opgelos.

** Deur die moontlikheid van 'n erediens en 'n ander gemeentelike byeenkoms op die Sondag kan Christus se opdrag aan die kerk, wat breër as erediens is, sinvol uitgevoer word.

* Die inhoud van die tweede byeenkoms is baie belangrik. In gemeentes waar baie mense op Sondae werk, is dit eintlik vanselfsprekend dat daardie gemeente op 'n gepaste tyd nog 'n erediens sal hou.

Waar die gemeente besluit om naas die gewone erediens 'n byeenkoms wat nie 'n erediens is nie, op die Sondag te hou, sal dit goed wees as hierdie tweede byeenkoms in een of ander vorm by die gewone erediens aansluit. Net soos in die geval van die erediens moet die klem by die gemeentelike byeenkoms op die verkondiging van die Woord val. (Dit sal uit die aard van die saak verkondiging in 'n ander gestalte as prediking wees.) In die lig van die kerklike tradisie sal dit goed wees as die tweede byeenkoms bestaan uit Bybelse onderrig. Dit is die geleentheid waar die Kategismus en Bybelstudie in hulle volle omvang aan die orde kan kom. Aangesien dit nie 'n erediens hoef te wees nie, kan hierdie onderrig so ingerig word dat die Woord ten volle aan die woord kom en die lidmaat 
met sy vrae en insette ook ten volle betrokke raak. Hierdie onderrig kan so ingerig word dat die gelowiges op 'n besondere wyse toegerus word vir hulle dienswerk in die wêreld.

Met die oog op klemlegging van die bediening van die Woord sou dit miskien beter gewees het as die bedieningstrukturekommissie van die Kommissie van die Algemene Kerkvergadering van die Nederduitsch Hervormde Kerk aanbeveel het dat die tweede byeenkoms van die gemeente op die Sondag 'n Bybelstudie of onderriggeleentheid moet wees en by uitsondering ook 'n Woord- en Sangbyeenkoms (liturgiese diens). In die aanbevelings word ook voorsiening gemaak vir gesamentlike eredienste van Hervormde gemeentes in een dorp of ring. Vanweë 'koinoniale' verbintenisse is sulke eredienste van tyd tot tyd baie goed. Veral met feesgeleenthede soos rondom Kersfees, Paasfees en Hervormingsfees dien die 'groot' ringsbyeenkoms om die besonderhede van die feesgeleentheid te onderstreep. Gedurende lang naweke en skoolvakansies is dit realiteit dat 'n groot aantal lidmate weg is met vakansie. Die klein aantal wat die tweede erediens van die gemeente bywoon, is demoraliserend vir die predikant en die paar mense teenwoordig.

* Ringskommissies hou noulettend opsig oor elke gemeente se Sondagviering. Slegs in oorleg met die ringskommissie kan 'n gemeente minder as twee byeenkomste op 'n Sondag hou.

* Uit hierdie aanbeveling is dit duidelik dat die bedieningstrukturekommissie die Sondag steeds sien as 'n besondere dag van die gemeente in diens van God. Die aantal ure wat die gemeente afstaan vir God se diens word nie verminder nie, maar net op 'n ander tyd benut en anders ingeklee. Die Ringskommissie se bysyn wil sê dat die orde wat bestaan, gehandhaaf gaan word.

\section{Literatuurverwysings}

Barnard, A C 1981. Die Erediens. Pretoria: N G Kerkboekhandel.

-- 1986. Die sinvolle aanddiens. Ongepubliseerde referaat gehou voor die Kongres van die Hervormde Teologiese Vereniging, Universiteit van Pretoria.

Beukes, J A 1988. Gaan ons nog kerk toe. 'n Ongepubliseerde ondersoek binne die Nederduitsch Hervormde Kerk van Afrika met die oog op die Algemene Kerkvergadering van 1989.

Beukes, M J du P 1987. Vernuwing van die erediens. Ongepubliseerde diktaatlesings. Departement Praktiese Teologie (Afd A), Universiteit van Pretoria. 
Calvyn, J s j. Institutie of onderwijzing in de christelijke godsdienst. Uit het Latijn vertaald door A Zizoo. Eerste deel boek I en II. Derde druk. Delft: Meinema.

De Wet, J I 1965. Liturgiek I. Ongepubliseerde diktaatlesings, Departement Praktiese Teologie (Afd A), Universiteit van Pretoria.

Dreyer, T F J 1990. Die tweede erediens. Ongepubliseerde voordrag voor die Raad vir Prediking en Erediens van die Nederduitsch Hervormde Kerk van Afrika.

Diensboek Nederduitsch Hervormde Kerk van Afrika 1988. Pretoria: KITAI.

Dijk, K s j. De Catechismuspreek in haar verscheidenheid. Franeker: T Wever.

Dressel, L C 1987. Dit het aand geword: Die herkoms en inkleding van die aanddiens.

Bloemfontein: Die NG Kerk Jeugboekhandel.

Engelbrecht, B J s j. Die Wet van God. Pretoria: KITAL.

Firet, J 1977. Het agogisch moment in het pastorale optreden. Kampen: J H Kok.

Haitjema, Th L 1962. De Heidelbengse Catischusmus als klankbodem en inhoud van het actuele belijden onzer kerk. Wageningen: $\mathrm{H}$ Veenman en zonen $\mathrm{N} \mathrm{V}$.

Hasselaar, J M (ed) 1986. Dr O Noordmans: Verzamiden Werken, Dee' VI: De Kerk en het leven. Kampen: Kok.

Kuyper, A C 1982. Sabbat moet 'n dubbele erediens wees. Die Hervormer 73.

Louw, D J 1980. Die stad in die mens. Pretoria: NG Kerkboekhandel.

Müller, J 1987. Vastheid, variasie en kreatiwiteit in die liturgie. Praktiese Teologie in Suid-Afrika 3.

Nagel, D W 1962. Geschichte des Christlichen Gottesdienst. Berlin: De Gruyter.

Nederduitsch Hervormde Kerk van Afrika 1976. Notule van die agt en vyftigste Algemene Kerkvergadering. Pretoria: NHKA Argief.

-- 1983. Notule van die sestigste Algemene Kerkvergadering. Pretoria: NHKA Argief.

-- 1989a. Notule van die een en sestigste Algemene Kerkvergadering. Pretoria: NHKA Argief.

--- 1989b. Kerkwet en bepalings. Pretoria: Gutenberg.

Nederduitse Gereformeerde Kerk 1986. Agenda en notule van Algemene Sinode van die Nederduitse Gereformeerde Kerk.

Nel, M 1987. Teologiese perspektiewe op gemeentebou. Pretoria: NG Kerkboekhandel.

Oberholzer, J P 1986. Die Heidelbergse Kategismus. Pretoria: KITAL.

Pieterse, H J C 1990. ' $n$ Erediens - uitsig op die gemeente, in gesprek oor die erediens. Teologiese huldigingsbundel aan prof $A C$ Bamard. Pretoria: NG Kerkboekhandel. 
Van der Merwe, C 1991. Die ouer se kerklik-godsdienstige verantwoordelikheid ten opsigte van sy kind. Ongepubliseerde en nog nie goedgekeurde DD-proefskrif, Universiteit van Pretoria.

Van der Westhuizen, H G 1975. Verslag aan die Kommissie van die Algemene Kerkvergadering oor die tweede erediens op Sondag. Ongepubliseerde Handelinge Kommissie van die Algemene Kerkvergadering van die Nederduitsch Hervormde Kerk van Afrika April/Junie.

... 1976. Aanbid God. Pretoria: HAUM.

Van Selms, A s j. De Zondag tuschen Farizeisme en Libertinisme. Nijkerk: G F Callenbach N V. (Nummer 3 uit serie onzse tijd.)

Van Wyk, D J C 1975. Verslag aan die Kommissie van die Algemene Kerkvergadering oor die tweede erediens op Sondag. Ongepubliseerde Handelinge van die Kommissie van die Algemene Kerkvergadering van die Nederduitsch Hervormde Kerk van Afrika, April/Junie.

Van Zyl, P J 1987. Die tweede erediens op Sondag is nie slegs 'n replika van die eerste diens nie en behoort daarom liturgies anders ingerig te word. Ongepubliseerde skripsie as deel van die vereistes vir die DD-eksamen, Departement Praktiese Teologie (Afd A), Universiteit van Pretoria.

Veldkamp, H s j. Zondags Kinderen kanttekeningen bij de Heidelhergse Catechismus. Deel II. Derde druk. Franeker: T Wever. 